\title{
Isfir Al-Mahata: A Newly Discovered Subsurface Oil Shale Deposit in Southern Jordan
}

\author{
Hani Alnawafleh ${ }^{1}$, Khaled Tarawneh ${ }^{1}$, Ali Ghannam ${ }^{2} \&$ Lutfi Abu-Sa'ad ${ }^{2}$ \\ ${ }^{1}$ Department of Mining and Mineral Engineering, Al-Hussein Bin Talal University, Ma'an, Jordan \\ ${ }^{2}$ Natural Resources Authority, Amman, Jordan \\ Correspondence: Hani Alnawafleh, Department of Mining and Mineral Engineering, Al-Hussein Bin Talal \\ University, P.O. Box 20, Ma’an, Jordan. E-mail: Hanialnawafleh@ahu.edu.jo
}

\author{
Received: May 15, 2013 Accepted: June 8, 2013 Online Published: June 18, 2013 \\ doi:10.5539/jgg.v5n3p12 URL: http://dx.doi.org/10.5539/jgg.v5n3p12
}

\begin{abstract}
This is the first study focuses on the characteristics of newly discovered subsurface oil shale deposit in Isfir Al-Mahata Area in the southern part of Jordan. This area considered as one of the promising oil shale resources that are located in the southern region. This study aims through mineralogical and geochemical analyses to shed light on the characteristics of this potential resource. Oil shale is described as bituminous chalk marl phosphatic rich at the bottom. A total of 115 meters of oil shale were penetrated and recorded. Oil content is about $6 \%$ in the first 80 meters and increases to $11 \%$ in the remaining part. Petrography indicates that the oil shale of this borehole is foraminiferal wackestone changes to grainstone in the lowermost part. Amorphous organic matter is filling foram's cavities and dispersed within the mineral matrix. The later consists mainly of calcite with minor amounts of quartz, clay and apatite. With exception of the lower most part, major and minor elements oxides reveals minor variation indicate stagnant formational conditions. High terrestrial input contribution is expected.
\end{abstract}

Keywords: oil shale, geochemistry, Jordan, mineralogy, bituminous chalk marl, wakestone

\section{Introduction}

Jordan has a huge potential of oil shale in the subsurface. Major oil shale (OS) deposits are located in the central part of Jordan (Alali, 2006). Deposit conditions are favourable for surface mining (Dyni, 2005; Alali \& Sawaqed, 2006). Since 1966, successive discoveries of OS deposits were recorded in Jordan. Despite of what has been discovered from the OS resource in Jordan, still oil shale prospecting and exploration is an important task. Previous oil shale research in Jordan focused on central Jordan and gave little attention to those in northern Jordan, where southern Jordan remaining unstudied. A number of local source rock evaluation and geological studies of oil shale (e.g., Amireh, 1979; Abed \& Amireh, 1983; Alnawafleh, 2007; Abed et al., 2009) have been carried out.

This study is part of research cooperation between the natural resources authority (NRA) and Al-Hussein Bin Talal University in Jordan, and aims to investigate a newly discovered subsurface OS deposit at the Area of Isfir Al-Mahata that is located $10 \mathrm{~km}$ south of Ma'an city in the southern part of Jordan (Figure 1). Four boreholes have been drilled. This investigation opens lines of research for exploration of OS in southern part of Jordan as this part of the country accommodates huge potential OS reserves and offers suitable research environment for OS exploration and mining. The value of this topic will encourages international researches and OS mining companies for future OS research and investment in Jordan.

\section{Geologic Setting}

The Jordanian OS is kerogen-rich bituminous limestone (Abed \& Arouri, 2006) deposited during Maastrichtian to Paleocene (Powell, 1989; Pufahl et al., 2006), and belongs to Muwaqqar Chalk-Marl formation (Abed, 2000). The generalized vertical section of the area is shown in Figure 2. Abed et al. (2005) linked the OS deposition to shallow marine conditions which is in contrast with other studies on similar rocks from the region (e.g., Abdel-Kireem et al., 1996; Lüning et al., 1998; Scheibner et al., 2001) which showed that OS deposition occurred in deep water environment. Alnawafleh (2007) stated that the organic matter (OM) in OS successions varies laterally and vertically and this variability has been recorded from West Yarmouk in northern Jordan to El-Lajjun and Sultani in central Jordan. Stratigraphically, oil shale overlain phosphate rocks indicating 
environmental conditions change from oxic during the deposition of phosphate to sub-oxic or anoxic during the deposition of OS (Alnawafleh, 2007).

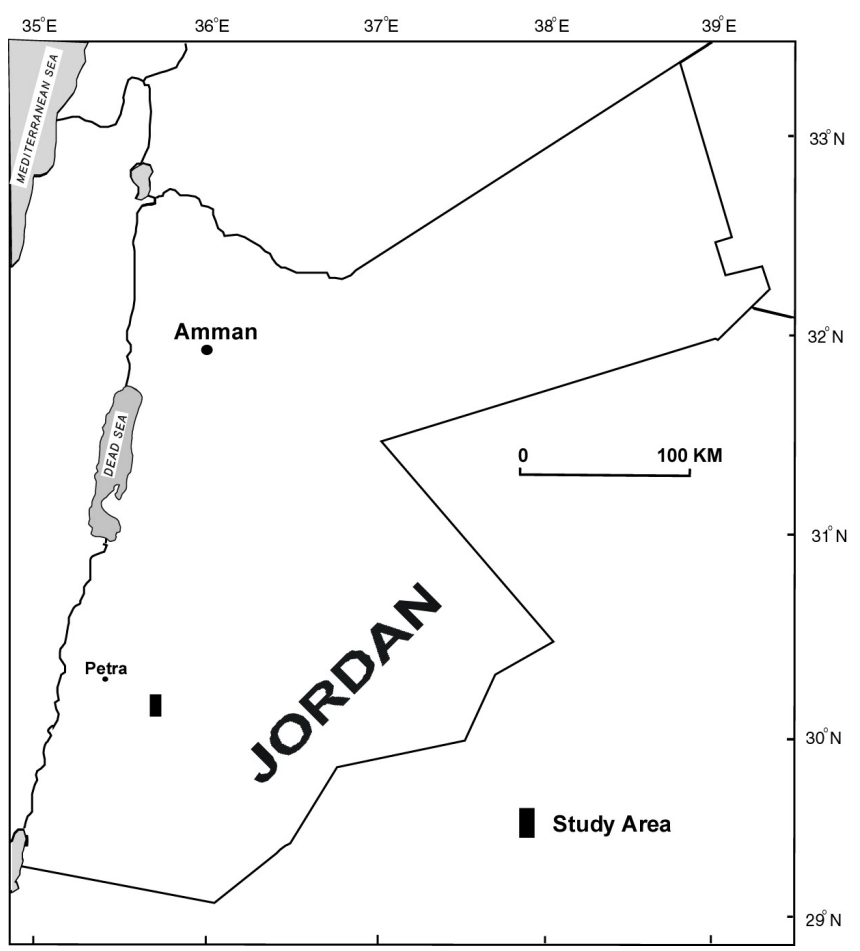

Figure 1. Location of Isfir Al-Mahata in southern Jordan

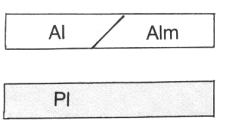

Alluvium Mudflat and Wadi Sediments

> Holocene

Fluviatile, Pleistocene Gravels

Pleistocene
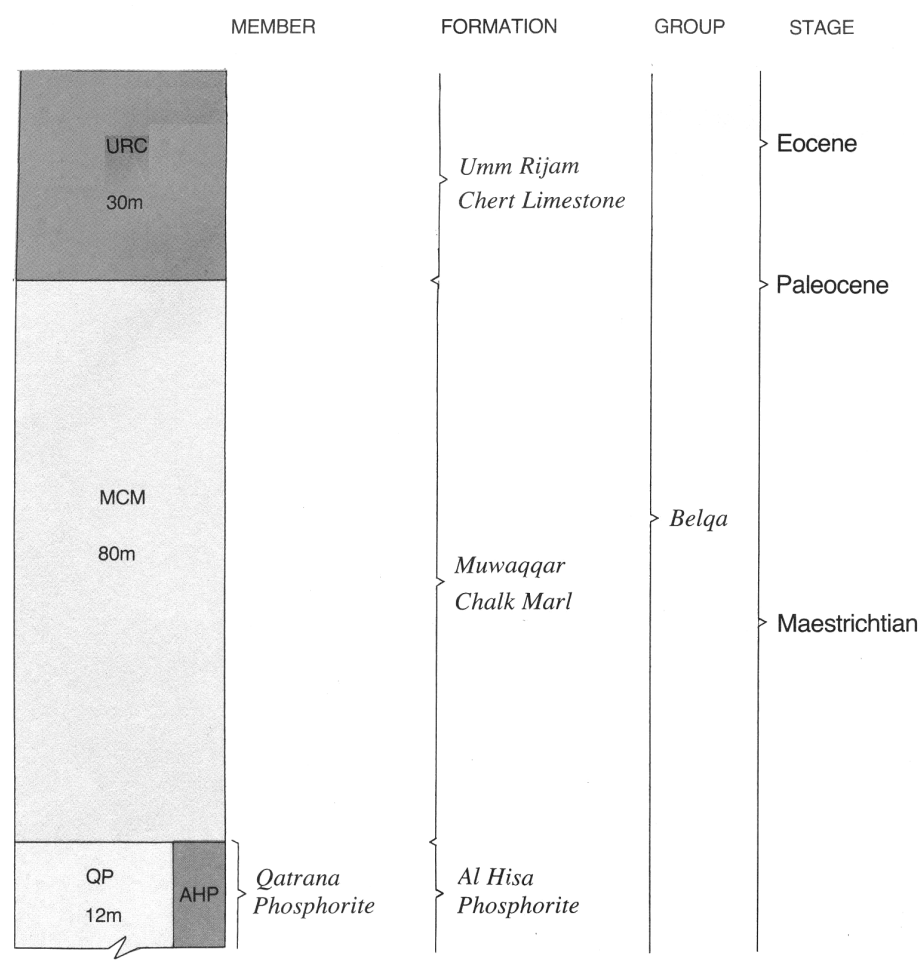

Figure 2. Generalized vertical section (not for scale) of Isfir Al-Mahata in southern Jordan (NRA, 1997) 


\section{Lithologic Description and Sampling}

Core OS samples from certain depths below surface were provided by the NRA from Isfir-1 borehole (BH). The coordination of Isfir-1 BH is $244145 \mathrm{E}$ and $960975 \mathrm{~N}$ with an elevation of $914 \mathrm{~m}$ above sea level. The recorded recovery is $100 \%$ with no loss in record. Oil shale was encountered at depth of $56 \mathrm{~m}$. A total of 115 meters of OS were penetrated and recorded. Overburden (OB) thickness is within the range of average OB thickness reported by Alali (2006) for central Jordan OS deposits (Table 1), while OS thickness is quite high.

Table 1. Average oil shale and overburden thickness of central Jordan oil shale deposits compared with this study

\begin{tabular}{cccccc}
\hline & El-Lajjun & Sultani & $\begin{array}{c}\text { Jurf } \\
\text { Ed-Darawish }\end{array}$ & $\begin{array}{c}\text { Attarat Um } \\
\text { El-Ghudran }\end{array}$ & $\begin{array}{c}\text { Isfir Al-Mahata (This } \\
\text { Study) }\end{array}$ \\
\hline $\begin{array}{c}\text { Oil Shale average } \\
\text { thickness (m) }\end{array}$ & 29.6 & 31.6 & 63.8 & 45 & 115 \\
$\begin{array}{c}\text { Overburden Average } \\
\text { thickness (m) }\end{array}$ & 25.8 & 69.3 & 47.3 & 53.2 & 56 \\
\hline
\end{tabular}

The lithological description of Isfir-1 BH is presented in Table 2. Oil shale from this area is described as bituminous chalk marl phosphatic rich at the bottom.

Table 2. Brief lithological description of Isfir-1 BH oil shale from Isfir Al-Mahata in southern Jordan

\begin{tabular}{|c|c|}
\hline $\begin{array}{l}\text { Depth } \\
(\mathrm{m})\end{array}$ & Lithological Description \\
\hline $0-3$ & Wadi sediments (sand, gravel, chert) with fragments of limestone. \\
\hline $3-56$ & Marl (top and bottom), chalky marl in the middle marl with limestone at the bottom. \\
\hline $56-71$ & $\begin{array}{l}\text { Bituminous chalk marl (Oil Shale), greenish grey, medium hardness, with bivalve fossils. Vertical } \\
\text { fractures filled by calcite. }\end{array}$ \\
\hline $71-99$ & Bituminous chalk marl, greenish to grey, medium hardness, with bivalve fossil. \\
\hline $99-101$ & Bituminous chalk marl, greenish grey to brownish grey, medium hardness, fractured. \\
\hline $101-110$ & $\begin{array}{l}\text { Upper part is bituminous limestone, dark grey, hard, with fragments of silicified limestone. Middle } \\
\text { and bottom parts are bituminous chalk marl, grayish brown, medium hardness, fractured at the } \\
\text { bottom. }\end{array}$ \\
\hline $110-112$ & $\begin{array}{l}\text { Bituminous chalk marl, grey, medium hardness, from } 111.5 \mathrm{~m} \text { to } 111.75 \mathrm{~m} \text {, bituminous marl, black, } \\
\text { grassy, from } 111.75 \text { to } 112 \text {, bituminous dolomatic limestone, light grey, hard. }\end{array}$ \\
\hline $112-120$ & Bituminous chalk marl, brownish grey, medium hardness, fractured. \\
\hline $120-129$ & $\begin{array}{l}\text { Bituminous chalk marl, greyish brown, medium hardness, } 120-120.80 \mathrm{~m} \text { fractured. Vertical fracture } \\
\text { filled by calcite }(124-125 \mathrm{~m}) \text {. From } 125-125.50 \mathrm{~m} \text {, bituminous marl, black, soft. }\end{array}$ \\
\hline $140-161$ & Bituminous chalk marl, dark greenish grey, medium hardness, fossiliferous. \\
\hline $161-171$ & $\begin{array}{l}\text { Bituminous chalk marl, greenish grey, medium hardness. Soft at the bottom (170-171), dotted of } \\
\text { white calcite. }\end{array}$ \\
\hline $171-173$ & Phosphate, bituminous, light greenish, with silty clay, greenish, medium hardness. \\
\hline $173-175$ & $\begin{array}{l}\text { Phosphate, slightly bituminous, greenish to light green, with limestone, creamy, off-white, medium } \\
\text { hardness. }\end{array}$ \\
\hline \multirow{2}{*}{$175-184$} & $\begin{array}{l}\text { Limestone at the top, marl, fragments of limestone, silty clay at the middle, chert with fragments of } \\
\text { limestone and fragments of calcareous dolomatic limestone at the bottom. }\end{array}$ \\
\hline & The End of Borehole \\
\hline
\end{tabular}




\section{Experimental Work}

Oil shale core samples were firstly cleaned, dried then crushed and pulverized to the desired size. Petrographical and mineralogical analyses were carried out in the laboratories of the Natural Resource Authority (NRA). Thin sections of fourteen representative samples were prepared and studied via transmitted white light microscope. Oil content and OS quality investigated through Fisher assay apparatus according to ISO 647 by thermal cracking method. Bulk density of thirteen selected samples determined via the density apparatus. Their total organic carbon (TOC) was determined via carbon determinator. Quantitative analysis of selected major and minor elements for forty three samples was obtained by x-ray fluorescence (XRF) method. Mineral phase's identification was carried out using the X-ray powder diffractometer (XRD) available at Al Al-Bayt University.

\section{Results and Discussion}

Oil shale of Isfir-1 BH consists of organic material which is the minor component and the inorganic mineral matter which makes the bulk of the samples. Variability of organic matter (OM) content can be inferred from the TOC depth profile (Figure 3).

Sharp increase in TOC content is recorded when change from the deposition of phosphate to oil shale that indicating formational condition change resulted in the preservation of larger amounts of organic matter. Based on TOC distribution, the oil shale within this borehole can be divided into two sections; the upper section $(80 \mathrm{~m})$ and the lower section $(35 \mathrm{~m})$. The later is quite rich in its OM content as indicated from high TOC values. The TOC content of the lower section is comparable with that of El-Lajjun OS deposit in central Jordan and such vertical variability in TOC content has been recorded in El-Lajjun deposit by Alnawafleh (2007).

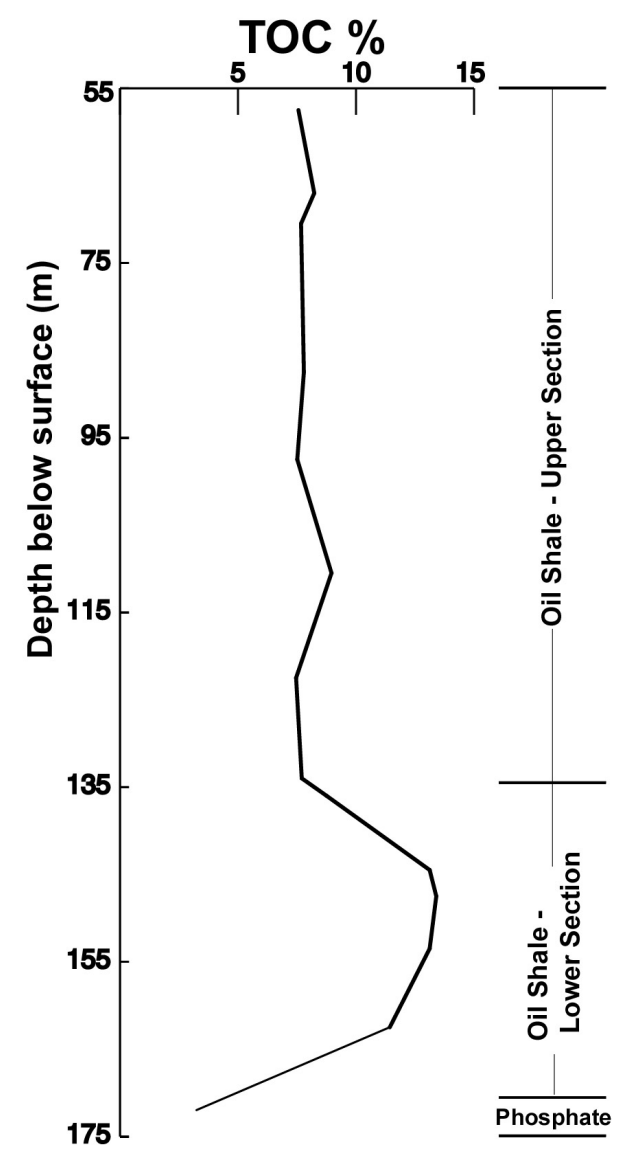

Figure 3. Depth profiles of total organic carbon

The OM is estimated using a conversion factor (1.22) for TOC values according to North (1985). The average content of OM of this deposit is quite lower than that of other deposits in Jordan reported by Alali (2006) (Figure $4)$. 

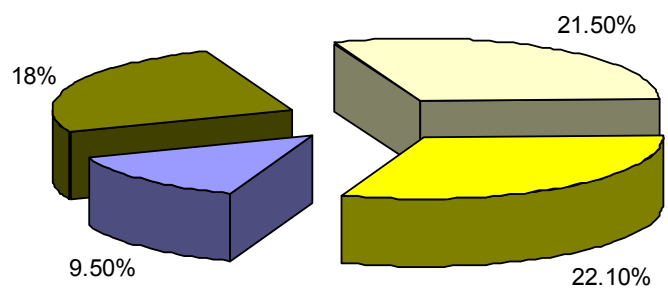

\author{
$\square$ Isfir Al-Mahata \\ (This Study) \\ $\square$ Jurf Ed-Darawish
}

$\square$ Sultani

$\square$ El-Lajjun

Figure 4. Average total organic matter content in selected Jordanian oil shale deposits compared to this study

Petrographic study shows planktonic foraminifera shells are dispersed within the fine mineral matrix (Figure 5A). The mineral matrix consists of calcitic shell fragments, OM, with minor amounts of quartz, clay and apatite. Foram's cavities filled with secondary calcite (Figure 5A, B) and amorphous organic matter. Petrographic study indicates that the OS of this borehole has foraminiferal wackestone texture changes to grainstone in the lowermost part. Phosphate rocks underline OS consist of Phosphatic pellets and bones (Figure 5C). This is comparable to that of El-Lajjun oil shale deposit (Alnawafleh, 2007). The OM in Jordanian oil shale from central Jordan is mainly of marine origin (Abed \& Arouri, 2006; Pufahl et al., 2006) with contribution of terrestrial sources (Alnawafleh, 2007). Within this area, OM from terrestrial origin can be expected as the area is very close the paleo-shoreline of Tethys ocean.

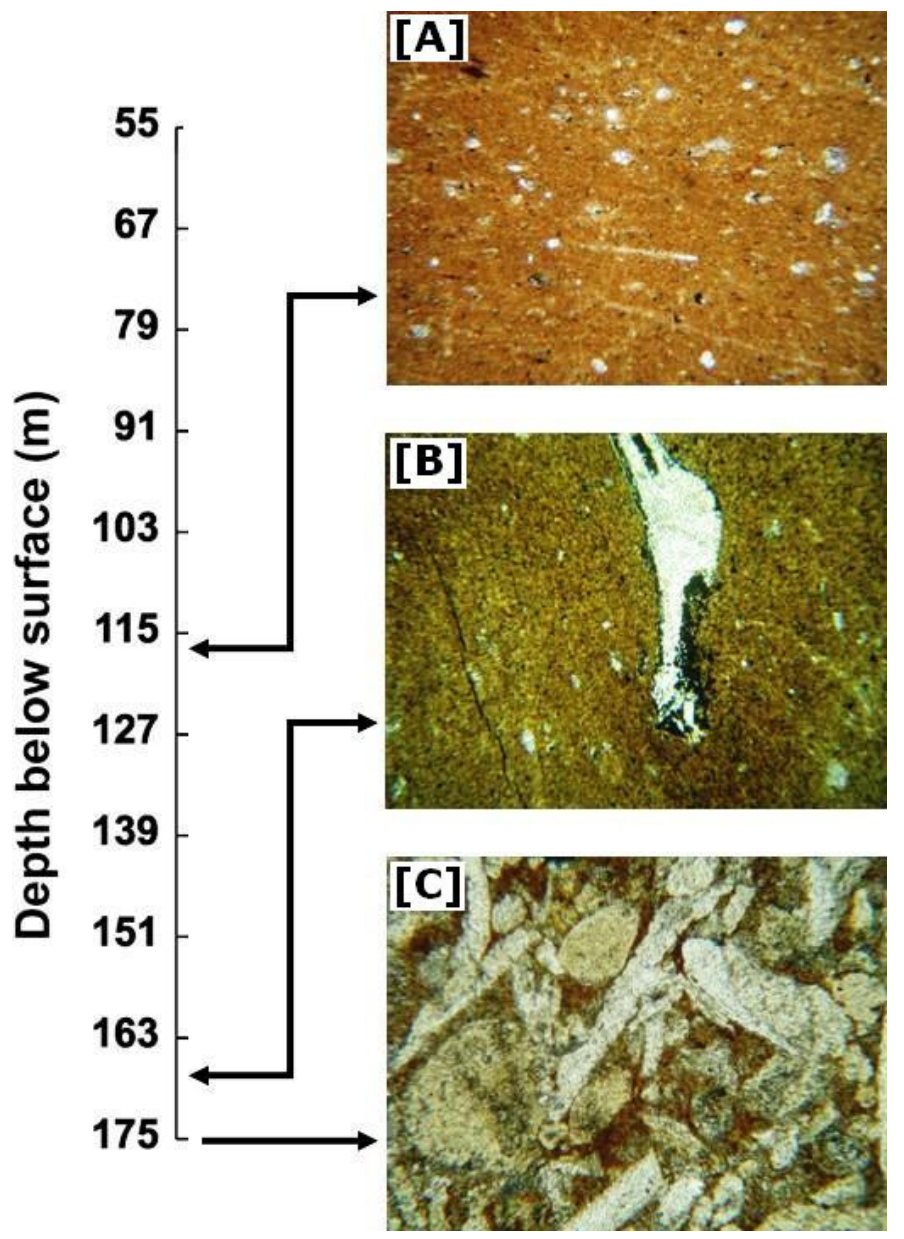

Figure 5. Photographs of oil shale samples under TWLM. [A, B] fine-grained limestone matrix embedded with planktonic foraminifera shells and phosphatic bones, foram's chambers are filled with secondary calcite. [C] Phosphatic pellets and bones 
The XRD results (Figure 6) and the chemistry of the studied samples indicate that the OS of Isfir-1 BH is made of OM, calcite, silica as quartz, phosphates as apatite, and minor amounts of clay minerals and pyrite. Overall, the mineralogy of this oil shale deposit is quite comparable to that of El-Lajjun in central Jordan studied by Alnawafleh (2007).

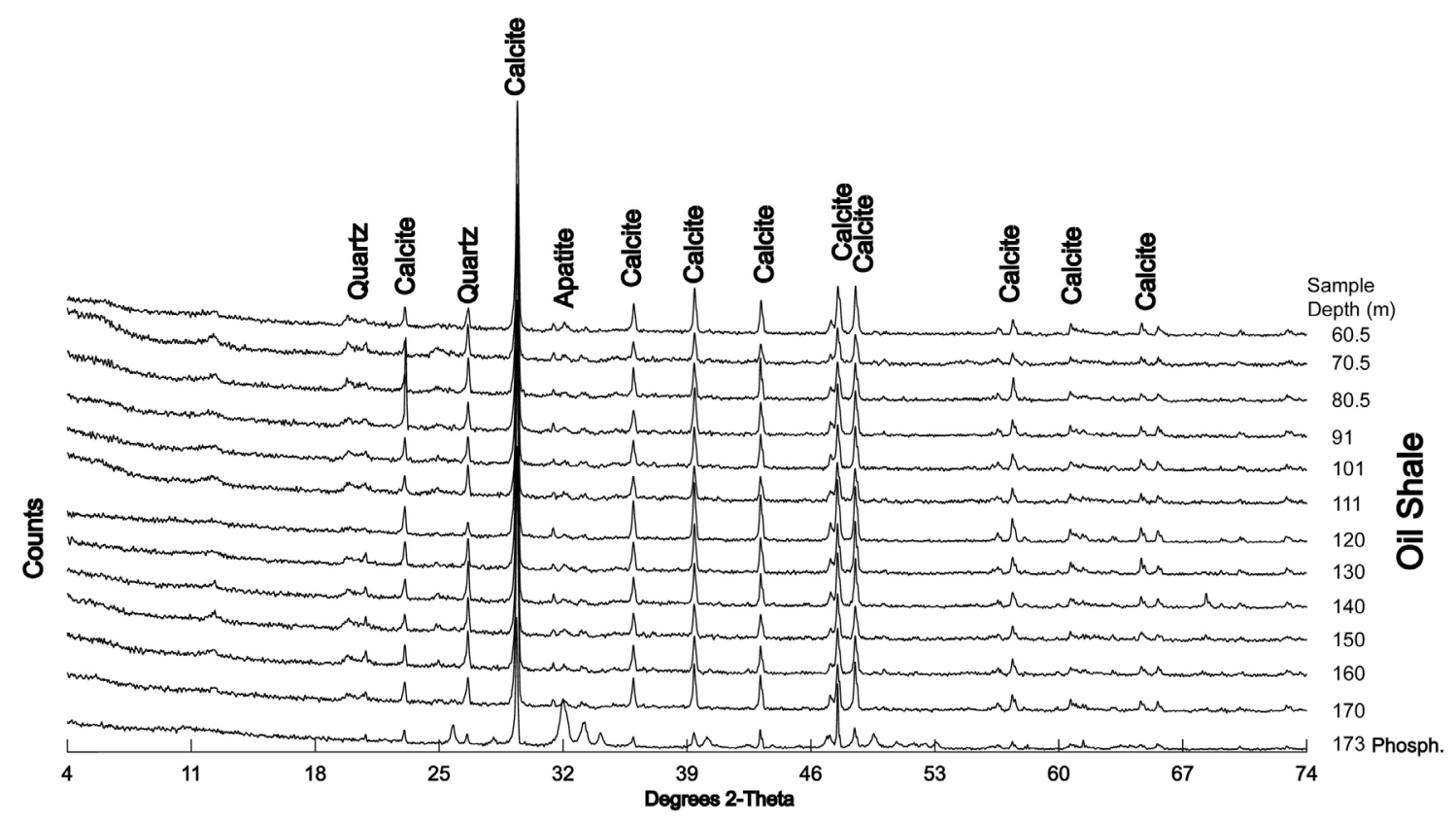

Figure 6. X-Ray diffraction patterns of selected oil shale samples from Isfir-1 BH

From the depth profiles of major and minor oxides (Figures 7 and 8) it can be seen that there is a sharp increase in quartz and clay contents when changing from phosphate to oil shale formation. Such transformation has been reported from El-Lajjun by Alnawafleh (2007). Clay content increase is expected as the area is close to the paleoshoreline of Tethys Ocean. Quite stagnant conditions during the formation of this oil shale deposit are indicated from the minor variations within the elements profiles. Observable change can be noticed in elements distribution from phosphate to oil shale.

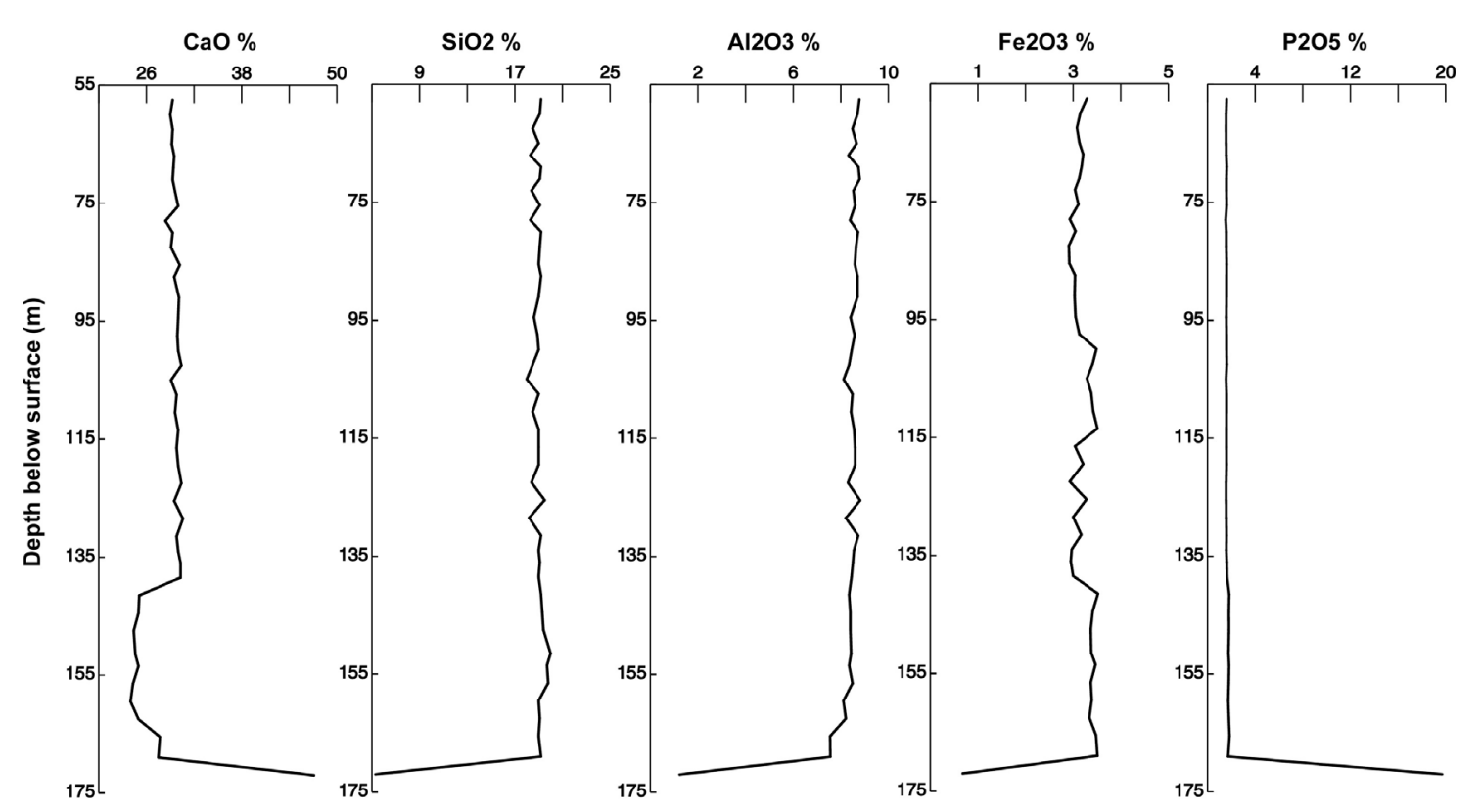

Figure 7. Depth profiles of major oxides 


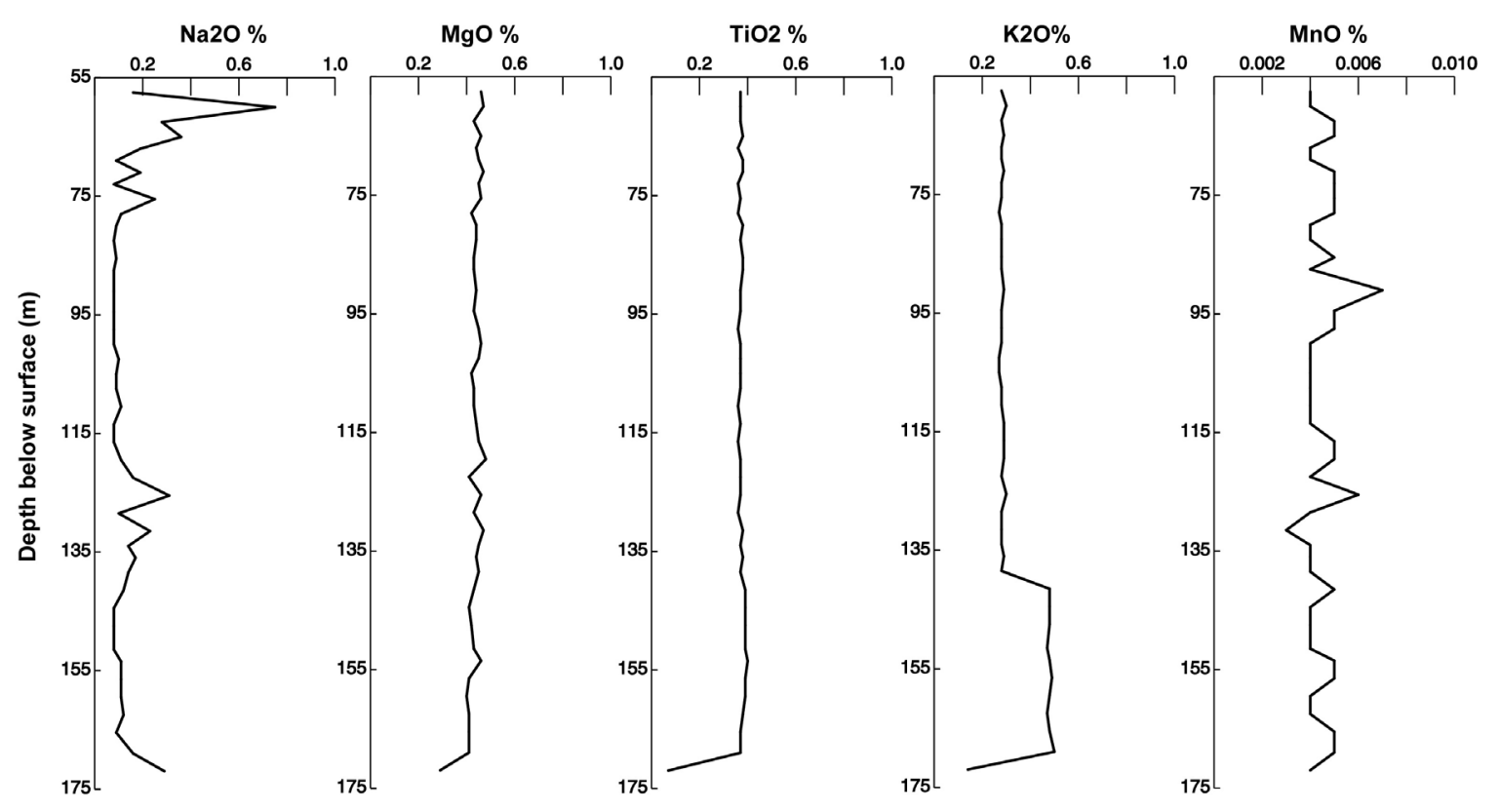

Figure 8. Depth profiles of minor oxides

The average content (wt\%) of selected major oxides from this deposit compared with that of selected OS deposits in Jordan is presented in Table 3. With exception of $\mathrm{Al}_{2} \mathrm{O}_{3} \%$, the values of other major oxides fit within the value range of other OS deposits.

Table 3. Average content (wt\%) of selected major oxides for selected Jordanian oil shale deposits compared to this study

\begin{tabular}{lcccc}
\hline & El-Lajjun & Sultani & Jurf Ed-Darawish & Isfir Al-Mahata (This Study) \\
\hline $\mathrm{SiO}_{2} \%$ & 16.13 & 26.26 & 6.3 & 18.98 \\
$\mathrm{CaO} \%$ & 30.43 & 26.30 & 38.37 & 28.65 \\
$\mathrm{Al}_{2} \mathrm{O}_{3} \%$ & 3.77 & 2.87 & 3.76 & 8.46 \\
$\mathrm{Fe}_{2} \mathrm{O}_{3} \%$ & 1.55 & 1.12 & 1.55 & 3.21 \\
$\mathrm{P}_{2} \mathrm{O}_{5} \%$ & 3.3 & 3.48 & 1.53 & 1.64 \\
\hline
\end{tabular}

Quite minor variation in the oil content from Fisher assay analysis is recorded in the upper section (Figure 9). The lower section is oil-rich. The variation in density with depth (Figure 10) is indicative for the change in the type of organic matter within the oil shale rocks. This OS deposit shows in average higher moisture content, lower density, and lower oil content (Table 4) compared with that of other OS deposits from Jordan as reported by Alali (2006) and Hamarneh (1998). 


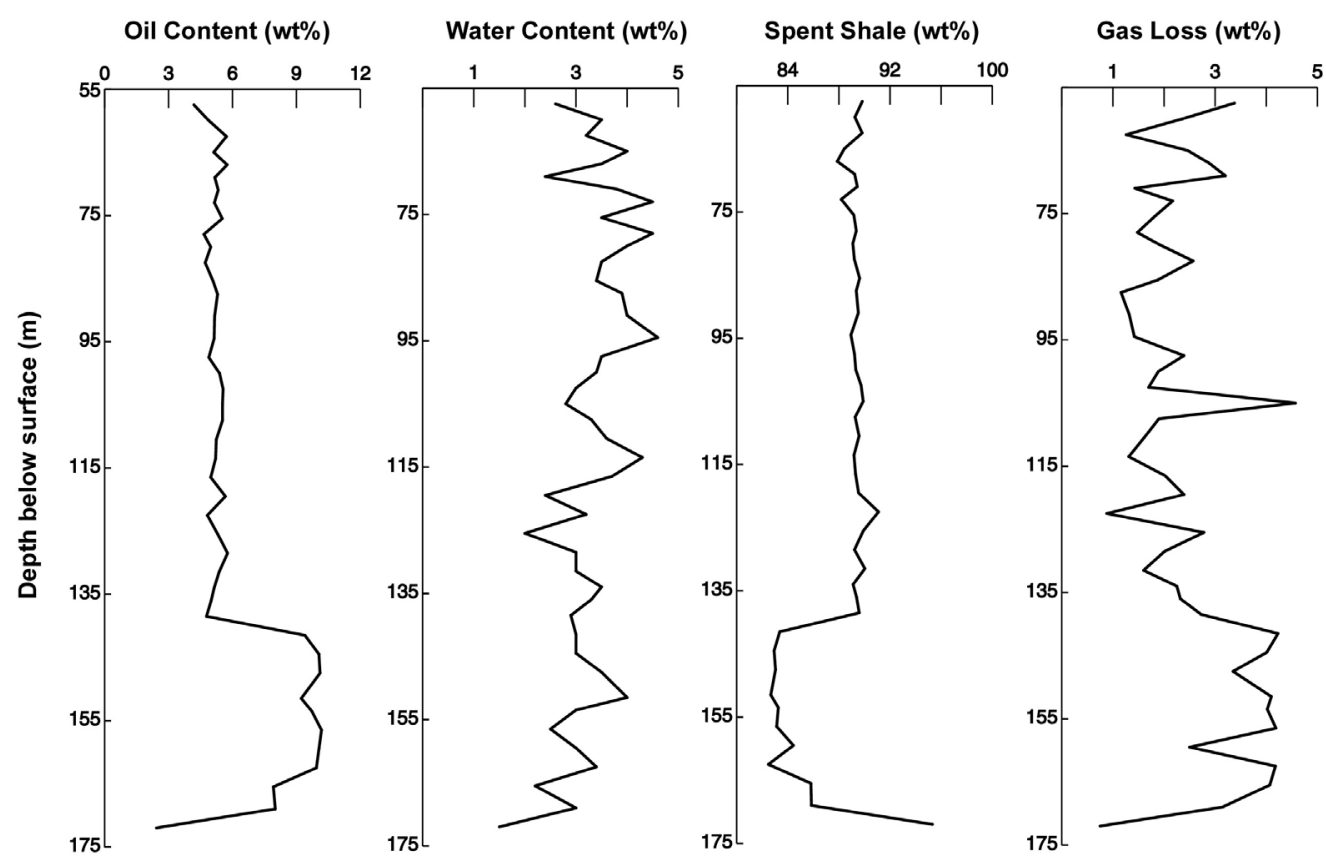

Figure 9. Depth profiles of Fisher assay analysis results

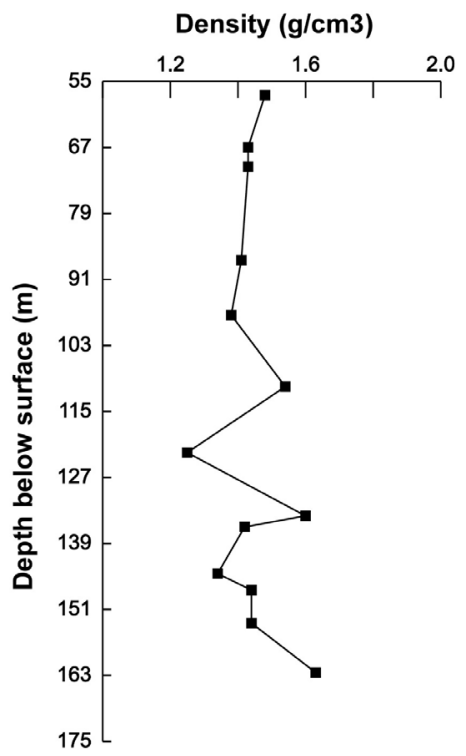

Figure 10. Density variation with depth

Table 4. Some physical and chemical properties of selected Jordanian oil shale deposits compared to this study

\begin{tabular}{lcccc}
\hline & El-Lajjun & Sultani & Jurf Ed-Darawish & Isfir Al-Mahata (This Study) \\
\hline Av. oil content $\left(\mathrm{wt}^{2} \%\right)$ & 10.5 & 7.5 & 5.7 & 6.08 \\
Bulk density $\left(\mathrm{g} / \mathrm{cm}^{3}\right)$ & 1.81 & 1.96 & 2.1 & 1.45 \\
Moisture $(\mathrm{wt} \%)$ & 2.43 & 2.6 & 2.8 & 3.34 \\
\hline
\end{tabular}




\section{Oil Shale Economic Potential}

The dramatic increase of oil prices worldwide has negatively affected the overall Jordan's Economic. The Jordanian government has implemented an adequate development strategy for Jordanian oil shale resources exploitation. This is obvious throughout the memorandums singed by the government of Jordan with many international companies (e.g. Shell and Estonian Energy Company) to carry out oil shale feasibility studies.

The NRA exploration studies of OS resources in Jordan reported in Alali (2006) indicated a huge geologic and mineable near surface reserves estimated to be more than 50 billion metric tons mainly located in the central part of Jordan. The reserve is unlimited and enormous in the northern part of Jordan. Continuous oil shale exploration and discovery of new OS deposits, especially in the southern part of the country, add more economic potential to this natural indigenous resource.

The discovery of the subsurface OS in Isfir Al-Mahata considered as the first indication of oil shale occurrence further south in the country. The expected reserve is quite huge. Detail reserve estimation study is needed. Therefore, the NRA should extend their drilling program in the next stage to delineate boundary of this deposit. Accordingly, the reserve potential of this deposit can be calculated.

From the mining point of view, favourable surface mining conditions are present. The area is not populated and OS has acceptable properties for processing. Such criteria are good indicators for the Jordanian government and OS international companies to consider utilization of oil shale resource in the south. Relatively high organic matter content within this deposit accordingly should direct any future exploration and mining plans.

\section{Conclusions}

This work presents characterisation of a subsurface oil shale deposit in the of Isfir Al-Mahata, southern Jordan. Subsurface oil shale rocks of Isfir Al-Mahata are composed of organic matter that form minor part of the bulk material and the major part is the mineral matter; mainly carbonate (calcite) with silica, phosphate and clay minerals. This subsurface oil shale is bituminous chalk marl phosphatic rich at the bottom. Oil content varies from $6 \%$ in the first 80 meters to $11 \%$ in the remaining part. Rock facies changes from foraminiferal wackestone to grainstone in the lowermost part. Amorphous organic matter is filling foram's cavities and dispersed within the mineral matrix that consists mainly of calcite with minor amounts of quartz, clay and apatite. Major and minor elements oxides variation is related to the variation in the formational conditions. Sharp changes were recorded in the transition between phosphate and oil shale. Stagnant formational conditions were prevailed during oil shale formation. The lower section in this deposit is oil-rich and could be potential for future mining and utilization.

\section{Acknowledgement}

Authors wish to thank the Natural Resources Authority staff for their assistance.

\section{References}

Abdel-Kireem, M. R., Schrank, E., Samir, A. M., \& Ibrahim, M. I. A. (1996). Cretaceous Palaeoecology, Palaeogeography and Palaeoclimatology of the Northern Western Desert, Egypt. Journal of African Earth Sciences, 22(1), 93-112. http://dx.doi.org/10.1016/0899-5362(95)00125-5

Abed, A., \& Arouri, K. (2006). Characterization and Genesis of Oil Shales from Jordan. Paper NO. rtos-A121. International Conference on Oils Shale: "Recent Trends in Oil Shale", 7-9 November 2006, Amman, Jordan.

Abed, A. M. (2000). The Geology of Jordan and Its Environment and Water (in Arabic). Publication of the Jordanian Geologists Association. Amman - Jordan.

Abed, A. M., Al-Arouri, K., \& Boreham, C. J. (2005). Source Rock Potential of the Phosphorite Bituminous Chalk-Marl Sequence in Jordan. Marine and Petroleum Geology, 22(3), 413-425. http://dx.doi.org/10.1016/j.marpetgeo.2004.12.004

Abed, A. M., \& Amireh, B. S. (1983). Petrography and Geochemistry of Some Jordanian Oil Shales from North $\begin{array}{lllll}\text { Jordan. Journal of } & \text { Petroleum }\end{array}$ http://dx.doi.org/10.1111/j.1747-5457.1983.tb00571.x

Abed, A. M., Arouri, K., Amireh, B. S., \& Zayed Al-Hawari, Z. (2009). Characterization and Genesis of Some Jordanian Oil Shales. Dirasat, Pure Sciences, 36(1), 7-17. 
Alali, J. (2006). Jordan Oil Shale, Availability, Distribution, and Investment Opportunity. Paper NO rtos-A117. International Conference on Oils Shale: "Recent Trends in Oil Shale", 7-9 November 2006, Amman, Jordan.

Alali \& Sawaqed. (2006). Oil Shale Resources Development in Jordan. Natural Resources Authority Report.

Alnawafleh, H. (2007). Geological Factors Controlling the Variability of Maastrichtian Bituminous Rocks in Jordan. PhD Thesis. Nottingham University.

Amireh, B. S. (1979). Geochemistry and Petrography of Some Jordanian Oil Shales. Unpublished M.Sc. Thesis. The University of Jordan - Amman, Jordan.

Dyni. (2005). Geology and Resources of Some World Oil-Shale Deposits. USGS Report 2005-5294.

Hamarneh, Y. (1998). Oil Shale Resources Development in Jordan. Natural Resources Authority, Jordan.

Lüning, S., Marzouk, A. M., \& Kuss, J. (1998). Late Maastrichtian Litho- and Ecocycles from Hemipelagic Deposits of Eastern Sinai. Egypt. Journal of African Earth Sciences, 27(3-4), 373-395. http://dx.doi.org/10.1016/S0899-5362(98)00069-4

North, F. K. (1985). Petroleum Geology (p. 607). London: Bulter and Tanner Ltd.

NRA. (1997). Geological Map of Isfir Al Mahatta \# 3150 II. Natural Resources Authority, Jordan.

Powell, J. H. (1989). Stratigraphy and sedimentation of the Phanerozoic rocks in central and south Jordan - Part B: Kurnub, Ajlun and Belqa Groups. Natural Resources Authority, Amman - Jordan, Bulletin 11, Geological Mapping Division.

Pufahl, Grimm, Abed, \& Sadaqah. (2006). Upper Cretaceous (Campanian) Phosphorites in Jordan: Implications for the Formation of a South Tethyan Phosphorite Giant, Sedimentary Geology v.161.

Scheibner, C., Marzouk, A. M., \& Kuss, J. (2001). Maastrichtian-Early Eocene Litho-Biostratigraphy and Palaegeography of the Northern Gulf of Suez Region. Egypt. Journal of African Earth Sciences, 32(2), 223-255. http://dx.doi.org/10.1016/S0899-5362(01)90005-3

\section{Copyrights}

Copyright for this article is retained by the author(s), with first publication rights granted to the journal.

This is an open-access article distributed under the terms and conditions of the Creative Commons Attribution license (http://creativecommons.org/licenses/by/3.0/). 